\title{
Pierre-Philippe Fraiture Modernity and the Belgian Congo
}

Pierre-Philippe Fraiture is Associate Professor in the Department of French Studies, University of Warwick (UK). He is the author of Sous l'empire du royaume (2003) and La Mesure de l'autre (2007).

Email: P-P.Fraiture@warwick.ac.uk

\section{Modernity and the Belgian Congo}

This article will explore the intellectual context in which French-Belgian colonial writing developed from the turn of the twentieth century to the late 1930s. This period is marked by a gradual shift from evolutionism to cultural relativism. The analysis will first focus on the Tervuren colonial exhibition of 1897 and the progressive emergence of Belgian africanism in the early twentieth century. Secondly, it will account for the ways in which this overall context bore witness to new and somewhat less Eurocentric conditions of possibility. Subsequently, the article will attempt to draw parallels between these more inclusive and seemingly less orientalising anthropological paradigms and the advent, first in France and then in Belgium, of a rejuvenated brand of colonial literature (or indigenous realism) which, for all its openness and eagerness to embrace modernity, did not result in radical rejections of colonialism on the part of its promoters. Finally, two Belgian novels in French - M. L. Delhaise-Arnould's Amedra (1926) and H. Drum's Luéii (1932) - will be analysed to appraise whether or not their authors' objective to reconstitute Congolese indigeneity is a strategy to oppose Belgian modernity against Congolese supposed pre-modernity. Key words: Africanism, French-Belgian colonial writing, Congo literature, modernity, M. L. Delhaise-Arnould, H. Drum, Museum of Tervuren.

\section{Art nouveau and empire}

Belgian colonisers introduced the Congo to modernity as they attempted to convert the locals to Christianity, implement new modes of capitalist production and imposed the European idea of the nation-state. The term "modernity" is very contentious as it is neither chronologically nor conceptually clear-cut (Giddens 1990). What I would like to demonstrate in this article is that this context, modernity, also generated dialogues between Belgian and Congolese artists and, ultimately, shaped and inflected Belgian modernism or aesthetic sense. This article will focus on colonial fiction in its post-evolutionist phase and endeavour to show that this corpus resulted from the same epistemological rupture as Francophone writing although the latter developed differently from the late 1930s onwards. In his many essays on the discursive basis of European colonialism, Valentin Yves Mudimbe (1973: 17-18) has recurrently shown that throughout the nineteenth century the human sciences (for instance the nascent philology and anthropology) became gradually dependent on concepts and paradigms first developed in natural sciences. Mudimbe deplores this subservience and contends, for instance, that misapplications of Darwin's theory on 
the origin of species underpinned the emergence of a body of writings in which races, and hence cultures, tended to be appraised and classified along a line of progress that reflected above all an ambition on the part of its Western promoters to dominate the rest of the world. Mudimbe (1973:17) argues that this classic positiviste-naturaliste or evolutionist model, started to subside in the first quarter of the twentieth century with the advent of a more relativist attitude to other races and cultures. This article will focus on the Congo in its literary and aesthetic relationship with Belgium during this post-evolutionist phase (1900-1940) and argue that, in spite of this epistemological shift, the new climate did not result in radical rejections of colonial paternalism.

This relationship started in earnest in the 1880s when the Congo Free State (CFS) was created and became the personal property of Leopold II, the constitutional king of the Belgians. Leopoldian rule in the Congo conjures up today, as it did in the early years of the twentieth century, images of genocides and ruthless capitalist exploitation in the heart of darkness. This article will not deal with this aspect, not because I do not find it worthy of attention but simply because the Red Rubber Scandal, as it is customarily referred to, is one of the most documented chapters of Central African history. What I intend to demonstrate here, however, is that Leopold's reign (18651909), and more specifically the occupation and early colonisation of the Congo in the 1880s, coincided with an aesthetic and intellectual renewal in Belgium and that the Congo, as an object of study or source of artistic inspiration, participated in this new climate.

This period, that is the Belgian fin de siècle, is marked by a greater openness and open-mindedness on the part of Belgian artists, playwrights, poets, novelists and publishers. Internally, there was an attempt to forge a more inclusive cultural and national idea and to consider Belgian culture as a homogeneous whole in spite of the coexistence of two national languages and many dialects. Edmond Picard, one of the key figures of fin de siècle Belgian modernity (and founder of the influential L'Art moderne) developed in 1897 the (poorly theorised) concept of âme belge (Belgian soul, Aron 1985). Picard argued that Belgian artists needed to display their âmebelgiste penchant, that is to say, an ability to fuse Latin and Germanic elements in their works. If one considers the literary production of the period, it is true that many writers such as Maurice Maeterlinck, Emile Verhaeren or Georges Rodenbach, who were Flemish but wrote in French, loosely adhered to this cultural agenda and developed a Belgian literary canon that became abroad, and particularly in Paris, the most obvious manifestation of Belgian authenticity. This era of cultural revival is also characterised by a much greater openness towards the outside. Brussels, which in Pauvre Belgique had been described by Baudelaire as an art-less city - "En Belgique, pas d'Art; l'Art s'est retiré du pays. Pas d'artiste excepté Rops" (In Belgium, there is no Art; Art has abandoned the country. There is no artist with the exception of Rops, (Baudelaire 1980 [1953]: 884) - became in the 1880s much more cosmopolitan and the scene of unprec- 
edented cultural exchanges, notably between Symbolist French and Belgian writers and Art Nouveau artists (Paque 1989).

The Congo was not excluded from this cultural reassessment. In the 1880 s and in the 1890s several colonial exhibitions were organised in Antwerp and Brussels. The most spectacular one was that of Tervuren in 1897, organised in the context of the International Exhibition of Brussels (Fraiture 2007: 45-48). The exhibition was so successful - it attracted 1.2 million visitors (Van Den Audenaerde \& Van Hoecke 1998:14) - that the colonial pavilion of Tervuren was gradually transformed into a fully-fledged Musée du Congo belge (or Museum van Belgish-Kongo). The museum was renamed after decolonisation and is now known as the Musée Royal de l'Afrique Centrale (or Koninklijk Museum voor Midden-Afrika), the Belgian equivalent of the Musée de $l^{\prime}$ homme, and is regarded as one of the most significant africanist centres in the world.

The 1897 exhibition had been staged as a tribute to Leopold's achievements in the Congo and to show the Belgian public the formidable potential of the newly acquired colony. Several sections were dealing with commerce, natural sciences, ethnography and the so-called Salon d'Honneur was exclusively devoted to art and craft, two domains that the fin de siècle aesthetic revolution had brought together. The first chapter of the exhibition catalogue was significantly devoted to the objects displayed in the Salon d'Honneur. Ivory was the centre of much attention as this material had enabled artists to revisit chryselephantine sculpture, a genre that had been first developed in Ancient Greece. Théodore Masui, the curator and the editor of the exhibition catalogue, noted that this renewal was "[...] définitivement $[. .$.$] parmi les grands$ événements artistiques de notre époque" (definitely [...] amongst the major artistic events of our time, [Liebrechts \& Masui 1897: 11]).

This emphasis on chryselephantine sculpture partly needs to be read against the background of the prevailing ethnocentrism. The use of ivory and its subsequent transformation into art is indeed a sort of mise en abyme of the colonial situation, in that it reiterates the idea that the Congo is a repository of raw materials to be refined in the more civilised metropolis. This explanation, however, cannot translate the complexity of the situation as this exhibition, somewhat peripherally it must be said, took also into account the aesthetic input from the Congolese. In the opening section of the exhibition catalogue, Masui remarks that the colonies " $[\ldots]$ peuvent apporter aussi $[\ldots]$ une contribution réelle au domaine du 'beau' [...]" (can also contribute effectively to artistic beauty) and he adds, more importantly, that local artists and craftsmen "[...] pourront aider [...] au développement de notre sens esthétique moderne" (will help to develop our modern aesthetic sense, [Liebrechts \& Masui 1897:3, my emphasis]. In another section devoted to pieces of furniture designed and exhibited by Belgian art nouveau figures such as Paul Hankar, Victor Horta, Gustave SerrurierBovy and Henry Van De Velde, Masui pointed out that the furniture designers' tour de force resided in the fact that they had incorporated into " [...] des meubles d'art de 
toute beauté $[\ldots]$ soit des tissus congolais, soit des ivoires, montrant ainsi le parti que l'on peut tirer aussi bien de la matière première que des œuvres mêmes des artisans noirs" (beautifully crafted furniture [...] either Congolese fabrics or ivories, demonstrating thus the benefits that can be drawn not only from raw materials but also from works made by black craftsmen themselves, [Liebrechts \& Masui 1897: 9, my emphasis]). The period is therefore marked by the gradual realisation that the strict cultural hierarchy established by nineteenth century evolutionist anthropology could no longer account for the complexity of Congolese artistry.

\section{Men on the spot}

This ability to acknowledge and include the (Congolese) other, albeit marginally, is also one of the key characteristics of the new anthropology that emerged at the turn of the century in the West (and its many colonies). In France and in Belgium, this new anthropology was developed in the wake of Durkheimian sociology. In 1896, Durkheim published an important essay on suicide. In this groundbreaking study, the French sociologist privileged two methodological options: the use of questionnaires and the practice of enquête directe (direct enquiry). In Belgium, this broad methodological orientation was adopted by Cyrille Van Overbergh, one of the founding figures of Belgian africanism in the earlier years of the twentieth century. Van Overbergh was unambiguously a man of his time. He was a member of the Catholic party, a high-ranking civil servant and also a prolific essayist (on Marxism, labour relations). He also belonged to Leopold II's inner circles of advisers and, as such, was a strong advocate of the civilising mission. He held the evolutionist view that it was the duty of the Belgian personnel in the Congo to "elevate" (the term belonged to the colonial discourse) the Congolese and reduce therefore the material and cultural gap between Belgium and the Congo. He believed that in order to be successful this personneladministrators, missionaries - needed to possess an intimate and expert knowledge of the Congo and its populations.

This simple belief is the premise of his africanist project. Van Overbergh set up the Bureau International d'Ethnographie (B.E. I.) within the Tervuren museum in 1905. The aim of this institution was to standardise and disseminate ethnographic research worldwide. In 1907, he also became the main founder and editor of the first Belgian africanist series, the so-called "Collection de Monographies ethnographiques". This series focused on the study of Central African ethnic groups. 14 volumes were published between 1907 and 1914. This series responded to a need to put ethnographic sciences - un peu égoïstes jusque ici (hitherto a little self-centred, Van Overberghe 1907: $\mathrm{x}$ ) - at the service of what Van Overbergh called a "campagne rationnelle de civilisation" (rational civilising campaign) and therefore bridge the gap between erudition and the Belgian imperial expansion. 
All monographs published in the series were structured on the basis of an ethnographic questionnaire of 202 questions. These questions, in turn, were organised within 7 major rubrics, such as la vie matérielle (material culture, questions 10-65), la vie familiale (family life, 65-100) or les caractères anthropologiques (anthropological characteristics, 187-202), that were supposed to cover, according to its conceiver - Prof. Halkin (Liège) - all customs and all aspects of everyday practices. Van Overbergh, who was an armchair anthropologist, wrote the first three monographs on the basis of the existing secondary sources available in the archive of the B. I. E. From volume IV, onwards, however, he relied on the knowledge and the expertise of "men on the spot" (the expression was coined by James Frazer) that is, people who had had substantial first-hand experience of the Congo and had consequently been able to conduct direct enquiries among its populations. These authors (R. P. Colle or Emil Torday) are still cited nowadays by prominent africanists such as Jan Vansina or Luc de Heusch. The series created by Van Overbergh became therefore a scientific forum in which individuals became acknowledged as authors. Having said this, the questionnaire used to compile the monographs somewhat curtailed their ability to assert their authorship and to speak as individual authors. All monographs can indeed be regarded as collective works since their authors had also to rely on a multiplicity of other informers and their sometimes discordant voices. What results from this collaboration (or co-lection) is that authors are no longer completely in control of the object under their scrutiny.

This emphasis on direct enquiries (and participant observation) transformed the relationship between the Congo, as a field of scientific enquiry, and the Belgian anthropological establishment. The questionnaire-based methodology favoured by Van Overbergh eroded the divide between armchair anthropologists, who were established figures of the Belgian academic apparatus, and africanist ethnographers (based in the colony). Traditionally, the preserve of interpretation rested with the former category, whereas ethnographers, in a state of institutional and geographical disconnectedness, were regarded as mere collectors of (arte)facts who were therefore credited with no real interpretative legitimacy. This new methodological impetus had two major consequences. Firstly, it marked the end of a type of anthropology which had hitherto been mainly exotic (in its etymological meaning of exterior or external) and spectacular (or scopic) and generated what Marc Augé, the French africanist, has designated as anthropologie du proche (anthropology of the here and now, [Augé 1992: 15]). Secondly, it also coincided with the emergence, in the name of a greater authenticity, of a new type of "men on the spot", the Congolese themselves, who were increasingly called upon to take part in this co-interpretation of their culture(s). 


\section{Indigenous realism}

The emergence of this anthropologie $d u$ proche coincides also with the development of a new type of exotic fiction in the first decade of the $20^{\text {th }}$ century. The era is marked by the arrival in the literary arena of a new breed of novelists. These writers, the Leblond brothers in France or Rudyard Kipling in Britain, developed a new relationship with the centre (with the métropole). They militated for a new authenticity. Truly authentic representations needed also, according to them, to be conveyed by "men on the spot", that is to say by people like themselves who had been brought up overseas (respectively in La Réunion and India) and had been able to observe local practices and sometimes participate in indigenous cultures. The Leblond brothers and Kipling had, as a consequence, somewhat severed the umbilical chord with France and Britain and this distance became key in the renewal of literary exoticism.

This new exoticism focused on the indigenous gaze and worldview, whereas oldstyle exoticism had above all privileged (and was still privileging) the other as seen (and spoken for), orientalised or invented by more remote and disengaged, non participative, onlookers. Many years before Bernard Dadié's or Jean Rouch's reversed anthropological narratives, the Leblond brothers produced with their novel En France (In France, 1909), one of the first anthropological accounts of Paris and Parisian daily practices as seen and experienced by Creole students from La Réunion. Paris became therefore an anthropological object. This poetic reversal had been radicalised by Victor Segalen in his ethnographic novel Les Immémoriaux (A lapse of memory, 1907). This piece had overall very few readers at the time of its publication but was celebrated in colonial circles where nouvel exotisme (new exoticism) became synonymous for colonial literature. The book possessed, according to the Leblond brothers all the necessary attributes of the nascent indigenous realism. Although Segalen was not a native of Tahiti, this erudite narration, and its detailed descriptions of Maori culture and worldview, gave the illusion of an authentically reconstructed indigenous gaze. In his posthumous Essai sur l'exotisme (Essay on Exoticism, 1978) Segalen described the main driving force behind this new poetics. He declared that his intention was to "prendre le contre-pied de ceux dont je me défends (put upside down the views of my opponents); the authors targeted here are Pierre Loti, Saint-Pol-Roux and Paul Claudel):

They expressed what they saw, what they felt in the presence of unexpected things and people from which and from whom they sought to experience a shock. Did they reveal what those things and people themselves thought and what they thought of them? For there is perhaps another shock, from the traveler to the object of his gaze, which rebounds and makes what he sees vibrate [...]. I attempted to express all that, the effect that the traveler has on the living milieu rather than the milieu's effect on the traveler, when I wrote about the Maori race. (Segalen 2002: 14$)^{1}$ 
In French-Belgian literature, it was felt that an analogous shift was needed to renew colonial writing and that colonial writers needed to embrace the new anthropological viewpoint that the Leblond brothers and Segalen had adopted about the French empire. Hitherto, this literary corpus (Belgian colonial fiction) had produced very few credible indigenous characters (Bogers \& Wymeersch 1987, Quaghebeur 1992, Halen 1993, Tshitungu Kongolo 2000, Fraiture 2003). The bulk of these narratives focused on European protagonists and their attempt to convert the new territory to Western practices. In this context, local characters played, in most cases, a subservient and ancillary role and appeared, with very few exceptions, as a mass of anonymous, interchangeable and silent individuals.

These narratives did not disappear in the interwar period but their frequency subsided with the advent of a new ideological climate towards the Congolese population. As in France, the war and its utter savageness had weakened Europe's claims to absolute superiority as a cultural model. Colonial officials and decision makers had internalized the lessons of pre-war anthropology and avant-garde. Since Les Demoiselles d'Avignon (The young ladies of Avignon, 1907), the Sub-Saharan aesthetic sense had gained in status and infiltrated the Western canon. Orality was no longer synonymous with cultural backwardness and Maurice Delafosse's much-acclaimed HautSénégal-Niger (Upper-Senegal-Niger, 1912) had proved that oral sources constituted a reliable material to establish the historical trajectories of peoples, which had often been regarded as a-historical. By the same token, it was now also accepted that the Congolese operated in highly ritualistic societies.

Gaston-Denys Périer, the most prominent and active colonial critic of the interwar period in Belgium advocated the introduction of this new literary perspective. $B a$ touala, véritable roman nègre (Batouala: A Negro novel), the 1921 Goncourt prize-winner by René Maran was in his eyes a model to emulate. Maran, a French black man of Antillean descent, was also a "man on the spot" as he had worked as colonial administrator for over ten years in French Equatorial Africa. The book had been very controversial in France because it had exposed the abusive nature of French colonialism. Périer, who was in charge of cultural affairs at the Belgian ministère des colonies, chose however to ignore this dimension. He understood that Batouala's emphasis on orality and representation of the African gaze would actually also disseminate efficiently and economically (metonymically) knowledge about Central Africa.

René Maran had in the preface to Batouala announced that his novel was constructed as a succession of eaux-fortes, that is to say a series of snapshots that would inform the readers on the major features of the Bantou tribe he was focusing on. Maran was therefore anticipating by a few years the investigating system that was to be developed by Marcel Mauss from 1926 onwards and, subsequently, applied by one of his most successful students, Marcel Griaule, in his work on the Dogons during the Dakar-Djibouti expedition. The main concept of this system is that of "total social 
fact", or the belief, as James Clifford (1988: 64) noted, "[...] that the totality of society is implicit in its parts [...]." Mauss was convinced that a representative sample of significant social facts would have the capacity of grasping "[...] synthetically an overdetermined cultural reality." Périer was therefore hoping that this new novelistic model would create a similar "synecdochic ethnography" (Clifford 1988: 64). He believed that it would also serve the colonial ideal. In the preface to Delhaise Arnould's Amedra. Roman de mœurs nègres du Congo belge (Amedra: A novel of Negro customs from the Belgian Congo, 1926), a Belgian "negro" novel strongly indebted to Batouala, Périer noted that:

It had been possible to predict for a number of years that black people from our colonial domain would play an increasingly important role in our works of fiction. The humanitarian tendencies of our colonial administration, the ambition to penetrate the black soul, the increasingly sophisticated studies to understand black society, the patient research into its organisation, its languages, arts and crafts, the increasingly evident focus placed on human issues by the colonisers could not but attract colonial writers. Literature which had been hitherto exotic shifted unsurprisingly towards negro subjects. (Delhaise Arnould 1926: 7-8)²

The Belgian politique indigène (i.e. the set of rules and measures implemented by colonial administrators to manage and contain the black personnel under their jurisdiction) remained until decolonisation paternalistic. For Périer (who was no less paternalistic), however, this politique needed also to contribute to the emergence of what he called a conscience belgo-congolaise (Périer 1930: 18). During his career, Périer militated therefore for a rapprochement between Congolese artists and writers and their European homologues. The premise of this aesthetic campaign rests on the idea that the concept of primitiveness does not necessarily apply to contemporary Congolese productions. Congolese art was, in his eyes, more than the expression of an atavistic or traditional call. He contented that it also belonged to the present and that music, sculpture and painting were arts vivants, a notion, which was then synonymous with contemporain or avant-gardiste (Halen 2000: 17-18). He felt that Congolese art needed to come out of the primitivist ghetto in which it had been confined for too long. As early as the beginning of the 1930s, he complained that museum and exhibition curators would routinely refuse to show, in the name of authenticity but also in an act of blatant censorship, objects or paintings unless they possessed clearly identifiable primitive features (Vellut 1994: 131). At the time of the 1931 International Exhibition of Colonial Art in Rome, Périer (in a letter quoted by Ricci [1998/9: 196]) was complaining that: "The exhibition curator has only kept a dozen portfolios, out of the very high number that I had submitted to him for Rome. He has only kept a few drawings of animals and men in loincloths and it has been impossible to convince him that blacks wear clothes or use European transport (bicycles etc.)." ${ }^{3}$ Later, in a 1936 article 
significantly entitled "L'Art vivant des noirs du Congo belge" (Modern art by Blacks from the Belgian Congo), Périer (1936: 3) also made the following point:

[...] it is not as art pieces that Congolese works have entered our museums. Their collection was driven by a scientific objective which focused above all on archaic productions. Until a few years ago, the most recently produced pieces had been neglected, admittedly because they did not offer ancestral characteristics. This amounted to condemning the arts of a disregarded community on two separate counts, firstly by robbing its heritage and classics and then by dismissing its contemporary artefacts. ${ }^{4}$

It is quite extraordinary to think that this view was expressed by a representative of the colonial power. This posture, his refusal to equate the Congo and its contemporary creations with an authenticity regarded as illusory or simply non-existent, echoes opinions voiced much later by thinkers such as Michel Leiris or Frantz Fanon. In his article "L'Ethnographie devant le colonialisme" (Ethnography before colonialism), published in Les Temps modernes in 1950, Leiris contented that it was an error:

[...] to reduce the ethnographic field to that of folklore and, by primarily focusing on the supposedly least contaminated societies (those which have remained, as it were, outside our modern life and are presented as some types of survivors), to neglect people who have been more strongly affected by Western civilisation: urban populations, for instance, those who have, according to their social classes, received the unfortunate label of évolués or the no less unpleasant appellation of "detribalised." (Leiris 1969 [1950]: 105)

By the same token, Fanon (1961:181), in Les damnés de la terre (The Wretched of the Earth), lampooned French africanism for producing mummified accounts of colonised cultures in the name of authenticity.

\section{Kings from elsewhere}

I would like now to shift my attention to two Belgian ethnographic narratives from the interwar period in order to draw further parallels between the new anthropology and this nascent indigenous realism (as represented by Périer). Amedra, the novel mentioned earlier, does reflect this tendency. The author was an acknowledged ethnographer and her novel can be considered as an attempt to provide, through a sort of "synecdochic ethnography" (Clifford), her readers with cultural facts on the Bapopoïe people, their hunting and eating habits, religious beliefs, sexual mores, marital practices, methods of governance, architectural preferences and festivals. When aggregated, all this information also conveys a synthetic picture of what is otherwise an "overdetermined" social or cultural "reality." On the other hand, however, this Bel- 
gian "negro" novel advocates also a new societal model. In her introductory Note de l'auteur, Delhaise-Arnould remarked that the novel "[...] is set a long time before the Europeans arrived in the land of the Bapopoïe" and that "no local, at the time, would have imagined that humans of a different colour existed and the mores of the tribe were free of any foreign influence" (Delhaise-Arnould 1926). ${ }^{6}$

Amedra, the main protagonist, is the village chief's daughter. She is used by the narrator to appraise the deficiencies of the Bapopoie marital practices and is portrayed as a victim of a tradition that does not give any say to female members of the community. Amedra has been promised to another chief who is not only presented as a tyrant but also as a polygamist. She will however reject him. In what is portrayed as an essentially backward and lawless milieu, she stands out and this difference is also physical. She projects herself along conventionally accepted aesthetic criteria: "Her body is covered with finely grained nkula powder [...]. Her face, lightly polished with pure scented oil, is surrounded by long braided hair, parted on both sides of her forehead which bore the tattoo of the tribe (Delhaise-Arnould 1926: 17). ${ }^{7}$ This tribal compliance does not, however, prevent her from creating her own aesthetics: "The pretty young woman has somewhat failed to comply with the customs of her race: her beautifully soft eyes are starred with long and thick eyelashes, whereas all Bapopoie females have their eyelids savagely plucked" (Delhaise-Arnould 1926: 18, my emphasis). ${ }^{8}$

She applies the same strategy to her sentimental life and it is highly significant that her first encounter with Esiague, the lover she freely chooses, takes place in a hostile forest where she feels increasingly disorientated: "[...] tree ferns, strange and unusually shaped and coloured plants crush and suffocate each other. [...]. A mouldy smell and clouds of unhealthy vapours float in the air which does not circulate properly" (Delhaise-Arnould 1926: 26-27). ${ }^{9}$ In this deleteriously luxuriant setting, Esiague appears as an agent of change: Amedra's fears subside because his presence coincides with a potentially new cultural stage. Esiague is also a pre-colonial Congolese but he is not a local; he is, conveniently it must be said, from outside, from another tribe. It is probable that the author - she was after all a noted ethnographer knew that in Bantou myths significant cultural changes were often symbolically brought about by external agents, by foreign princes who would fall in love with indigenous princesses, marry them, seize power and introduce new cultural practices. As the Belgian structuralist Luc de Heusch has abundantly shown in his anthropological studies on Central Africa, Bantou kings often came from elsewhere. This process is reminiscent of the civilising mission as it was conceived by the Belgians. Esiague and Amedra, the ideal couple imagined by the author, advocate - as all Belgian colonial officials or missionaries - a selective reform of traditional culture. Their failure (Esiague is assassinated and Amedra commits suicide) is a stark reminder of the tasks ahead: polygamy needs to be kept in check, law and order enforced and 
the forest - so rich but at the same time so uncontrollable - must be converted into a readily exploitable domain.

Luéji ya Kondé (Luéji, Daughter of Kondé, 1932) by Henri Drum is another example of an ethnographic novel. This narrative focuses on the Lunda princess Luéji, a part historical, part mythical figure. Luéji lived in the seventeenth century and is still remembered nowadays as the founding mother of an immense territory (the Lunda) spread across Angola, Zambia and the Democratic Republic of the Congo. In this learned but plainly written novel, Drum pays tribute to Lunda culture, to the subtleties of its religious rites and to the efficiency of its political system. This system was so flexible that the Lunda dynasty remained from 1600 to 1850 the most prominent and influential Central African power. In the context of Belgian colonialism in the 1930s, Drum's posture was very unorthodox as the administration was actively engaged in a process of ethnic dismembering and ethnic re-engineering of the Congolese territory (Bustin 1975). The aim of this exercise was to increase the control of the colonial administration over the territory and to curtail the influence of prominent ethnic entities such as the Lunda. Drum's position is unorthodox because he was, with other dissenting administrators, militating for the establishment of a politically semi-autonomous Lunda province. His ethnographic novel can therefore be regarded as a Francophone Ur-text because it celebrates the Lunda collective memory and mythology and seems also to be implying that this cultural richness should constitute the premise of future autonomy.

Drum's text, however, is more than a straightforward glorification of Bantu heritage. It also translates the willingness to build this communauté belgo-congolaise evoked earlier (regarding Périer) and to praise Belgian imperialism as a tool to achieve this goal. Drum's novel is a cultural collage and, as such, resonates with what Edward Said noted in Culture and Imperialism with regard to the use of the past in imperial texts. Said contends that these texts are profoundly ambiguous and are often the discursive sites of "overlapping territories and intertwined territories":

There is in all nationally defined cultures [...] an aspiration to sovereignty, to sway and to dominance. [...]. At the same time, paradoxically, we have never been as aware as we are now of how oddly hybrid historical and cultural experiences are, of how they partake of many often contradictory experiences and domains, cross national boundaries, defy the police action of simple dogma and loud patriotism. Far from being unitary or monolithic or autonomous things, cultures actually assume more "foreign" elements, alterities, differences, than they consciously exclude (Said 1994 [1993]: 15).

A similar "hybrid historical and cultural experience" would seem to be at work in Luéji inasmuch as Drum uses Bantu history to praise the benefits of imperialism. Drum regards colonialism as a mutually beneficial and enriching process. In this 
respect, it is significant to point out that he presents Lunda expansionism and imperialism as the result of a successful and symbiotic encounter between two ethnic groups. At the beginning of the novel, Luéji is controlling a cluster of a few villages; at the end of the narrative, however, she is said to be the empress of a territory four times larger than France. In the meantime, she meets Ilunga, a prince from the Luba ethnic group, and becomes his wife. This union is a mise en abyme of the colonial encounter and is also supposed to be marking the passage from nature to culture and from a matriarchal to a patriarchal system. Ilunga, as a Luba, is the representative of a higher and more sophisticated cultural order (as Esiague in Amedra, and Leopold II in "real life", he is also a "king from elsewhere") and, as such, is able to introduce Luéji and her people to new rites and customs, material culture and, last but not least, to the idea that expansionism can bring about benefits not only to the conquerors but also to the inhabitants of the conquered territories.

\section{Conclusion}

Overall, Belgian fiction about the Congo resulted from the anthropological modernity that I have described in this article. This intellectual context is also that of Francophone literatures: in the early 1930s, during their Parisian exile, Césaire and Senghor had indeed praised the works of contemporary anthropologists - for instance Delafosse and Frobenius - for their attempts to rehabilitate "negro" cultures from Africa. One important distinction needs however to be made with regard to this relationship between colonial writing and Francophone fiction. Colonial fiction remained until decolonisation driven by a very strong political agenda, that of the ultimate conversion of the other. Even in the most subtle and informed narratives, Belgian colonial writers often praised in the other's culture those practices that could unambiguously be adopted by the newly imported Western modernity. This perspective also meant that the type of indigenous realism that was promoted by men such as Périer in the interwar period became increasingly formalised and formulaic. They also tended to set local customs in stone, read their articulation along an essentialist line and resist any attempts, on the part of the locals, to renew artistic and writing practices. Paradoxically, as Fanon (1961: 181) remarked, colonialists became les défenseurs du style indigène (the promoters of the indigenous style) and the advocates of an authenticity which no longer reflected the present.

In most Belgian "negro novels" written until the Congolese independence, the same thematic pattern prevailed..$^{10}$ The conversion of the locals was represented as a positive, albeit painful process initiated by some enlightened messiah-like figures such as Amedra. These agents were often female characters. In the history of contacts between the Belgians and the Congolese, women played a comparatively minor role. As an essentially male enterprise - it slowly changed after the First World War - 
Belgian colonization brought above all men from both sides into contact. Somehow, it was felt that European modernity had bypassed women, particularly in rural areas. They were regarded ambiguously as the victims of a male-dominated tradition, and, at the same time, as the paradoxical guarantors of this very tradition. It was thought that their conversion or emancipation would produce a much more radical transformation of traditional (or pre-modern) culture and pave the way to a more acceptable compromise between Bantou customs and European modernity.

In his wide-ranging and erudite studies of the relationship between the human sciences - and above all social anthropology - and (Belgian) colonial discourse, $\mathrm{Mu}$ dimbe argues that professional ethnographers and Christian missionaries did belong to the same archaeological milieu. In The Invention of Africa, he identifies two major stages in the evangelisation of the Belgian Congo. Firstly, the so-called "missionary theology of salvation" according to which the Congolese is a pagan who needs to be converted in order to be saved from damnation (Mudimbe 1988: 53-56). Secondly, the "theology of indigenizaton" in which the Congolese are no longer regarded exclusively as pagans but as potential Christians (Mudimbe 1988: 57-59). This new theology, which was explicitly encouraged by the papacy after the First World war, attempted to identify in local religions so-called pierres d'attente de la foi (Pirotte), that is, African cornerstones, or principles, on which Christianity could be anchored and, subsequently, strengthened via the creation of a local clergy. Although Mudimbe recognises a positive evolution from the first to the second type of theology (which incidentally marks also the passage from evolutionism to cultural relativism), he concludes that this move to a more sympathetic (less ethnocentric) approach to Congolese culture was ultimately motivated by the necessity felt by the Church to renew what he calls its "tactics and strategies of domestication" (Mudimbe, 1994: 114-29). The evolution of colonial writing, and its assumption of anthropological modernity, needs also to be read as yet another tactic or strategy to domesticate Congolese otherness.

Notes

1 "Ils ont dit ce qu'ils ont vu, ce qu'ils ont senti en présence des choses et des gens inattendus dont ils allaient chercher le choc. Ont-ils révélé ce que ces choses et ces gens pensaient en eux mêmes et d'eux? Car il y a peut-être, du voyageur au spectacle, un autre choc en retour dont vibre ce qu'il voit. [...] Tout cela, réaction non plus du milieu sur les voyageurs, mais des voyageurs sur le milieu vivant, j'ai tenté de l'exprimer pour la race maorie." (Segalen 1978: 17-18)

2 All subsequent translations are mine. "Sans doute, pouvait-on prévoir, depuis quelques années, que l'homme noir de notre domaine africain prendrait une place plus grande dans les ouvrages romanesques de chez nous. Les tendances humanitaires de notre politique indigène, le souci de pénétrer l'âme congolaise, les recherches de plus en plus attentives en vue de connaître la société noire, les études patientes sur son organisation, ses idiomes, ses arts et métiers, le rôle de plus en plus marquant accordé à l'élément humain dans l'œuvre colonisatrice ne pouvaient laisser indifférents les écrivains coloniaux. Nécessairement la littérature consacrée à l'exotisme s'orientait vers les Nègres." (Périer in Delhaise Arnould 1926: 7-8)

3 “L'architecte de l'exposition n'a retenu pour Rome qu'une douzaine de cartons sur le nombre imposant que je lui avais soumis. Il n'a retenu que quelques desseins d'animaux et d'hommes en 
pagne, impossible de lui faire admettre des nègres habillés ou usant des moyens européens (bicyclettes etc.)." (Périer in Ricci 1998/9: 196)

4 “[...] ce n'est point à [...] titre artistique que les ouvrages congolais sont entrés dans nos musées. La récolte en a été faite dans un but scientifique, embrassant surtout les productions archaïques. On négligeait jusqu'en ces toutes dernières années, les plus récentes, sous le prétexte qu'elles n'offraient pas les caractéristiques ancestrales. C'était condamner deux fois l'Art d'une humanité non consultée, d'abord en lui ravissant ses souvenirs, ses classiques, puis en décourageant les réalisations actuelles." (Périer 1936: 3)

5 "[...] de réduire le champ ethnographique à celui du folklore et, donnant la primauté aux sociétés réputées les moins contaminées (soit : celles qui sont restées pour ainsi dire hors circuit de notre vie moderne et se présentent un peu à la manière de survivances), de laisser de côté les gens sur qui l'emprise de la civilisation occidentale se fait plus fortement sentir : ceux des villes, par exemple, ceux qu'on désigne, selon la classe sociale à laquelle ils appartiennent, sous le nom fâcheux d'évolués et sous celui, guère moins désagréable, de 'détribalisés'." (Leiris 1969 [1950]: 105)

6 " [...] se déroule longtemps avant l'arrivée des Européens dans le pays des Bapopoïe. [...] aucun indigène, à cette époque ne soupçonnait l'existence d'être humains d'une autre couleur et les mœurs de la tribu étaient exemptes de toute importation étrangère." (Delhaise-Arnould 1926: s. p.)

7 "Le corps fardé d'un grain fin de poudre de nkula [...]. La figure, polie légèrement d'huile pure aromatisée, est encadrée de longs cheveux roulés en cordelettes, partagés aux deux côtés du front orné du tatouage de la tribu." (Delhaise-Arnould 1926: 17)

8 "La coquette jeune fille a quelque peu enfreint la coutume de sa race: de longs cils épais frangent ses yeux très doux, tandis que toutes les Bapopoïes ont les paupières sauvagement épilées." (DelhaiseArnould 1926: 18, my emphasis)

9 “[...] des fougères arborescentes, une végétation $[. .$.$] aux formes multiples, étranges, aux coloris les$ plus invraisemblables, s'entassent, s'étouffent mutuellement. [...] Une odeur de moisi, des bouffées de vapeur malsaines [...] flottent dans l'air qui circule mal." (Delhaise-Arnould 1926: 26-27)

10 See for instance Luéji, Amedra but also Chantal Roy's Thubi, fille noire or Joseph Esser's Matuli, fille d'Afrique.

\section{Works cited}

Aron, Paul. 1985. Les Écrivains belges et le socialisme, 1880-1913: l'expérience de l'art social d'Edmond Picard à Émile Verhaeren. Brussels: Labor.

Augé, Marc. 1992. Non-Lieux. Introduction à une anthropologie de la surmodernité. Paris: Seuil.

Baudelaire, Charles. 1980. Pauvre Belgique. In Baudelaire. CEuvres complètes, "Bouquin". Paris: Laffont, $875-90$.

Bogers, Koen \& Patrick Wymeersch. 1987. De Kongo in de Vlaamse Fiktie en Reisverhalen. Brussels: C. E. D. A.F.

Bustin, Édouard. 1975. Lunda under Belgian Rule. The Politics of Ethnicity. Cambridge: Harvard University Press.

Clifford, James. 1988. The Predicament of Culture. Twentieth-Century Ethnography, Literature and Art. Cambridge, London: Harvard University Press.

Dadié, Bernard. 1959. Un Nègre à Paris. Paris: Présence africaine.

Delafosse, Maurice. 1912. Haut-Sénégal-Niger: le pays, les peuples, les langues, l'histoire, les civilisations. Paris: Larose.

Delhaise-Arnould, Marie-Lou. 1926. Amedra. Roman de mours nègres du Congo belge, preface by GastonDenys Périer. Brussels: La Renaissance d'Occident.

Drum, Henri. 1932. Luéji ya kondé. Brussels: Éditions de Belgique.

Esser, Joseph. 1960. Matuli, fille d'Afrique. Paris \& Brussels: Elsevier

Fanon, Frantz. 1961. Les damnés de la terre, preface by Jean-Paul Sartre. Paris: Maspero.

Fraiture, Pierre-Philippe. 2003. Le Congo belge et son récit francophone à la veille des indépendances. Sous l'empire du royaume. Paris: L'Harmattan.

2007. La Mesure de l'autre. Afrique subsaharienne et roman ethnographique de Belgique et de France (19181940). Paris: Éditions Champion.

Giddens, Anthony. 1990. The Consequences of Modernity. Cambridge: Polity Press. 
Halen, Pierre. 1993. Le Petit Belge avait vu grand: une littérature coloniale. Bruxelles: Éditions Labor. 2000. Les douze travaux du congophile: Gaston-Denys Périer et la promotion de l'africanisme en Belgique. Textyle, 17/18 : 139-50.

Heusch, Luc de. 1972. Le Roi ivre ou l'origine de l'État. Paris: Gallimard.

1991. The king comes from elsewhere. In A. Jacobson-Widding (ed.). Body and Space. Symbolic Models of Unity and Division in African Cosmology and Experience. Stockholm: Almqvist \& Wiksell International, 109-17.

Liebrechts, Charles \& Théodore Masui (eds). 1897. Guide de la section de l'État Indépendant du Congo à l'exposition de Bruxelles-Tervueren en 1897. Brussels: Imprimerie Veuve Monnom.

Leblond, Marius-Ary. 1909. En France. Monaco: Imprimerie Nationale de Monaco.

Leiris, Michel. 1969 [1950]. L'ethnographie devant le colonialisme. Cinq études d'ethnologie. Paris: Denoël/ Gonthier, 83-112.

Maran, René. 1921. Batouala. Véritable roman nègre. Paris: Albin Michel.

Mudimbe, Valentin-Yves. 1973. L'Autre Face du royaume: une introduction à la critique des langages en folie. Lausanne: L'Age d'Homme.

.1988. The Invention of Africa: Gnosis, Philosophy, and the Order of Knowledge. Bloomington, London: Indiana University Press.

. 1994. The Idea of Africa. Bloomington, London: Indiana University Press, James Currey.

Paque, Jeannine. 1989. Le Symbolisme belge. Brussels: Labor.

Périer, Gaston-Denys. 1930. Panorama littéraire de la colonisation belge. La littérature coloniale belge, illustrated by Djilatendo. Brussels: Albert Dewit.

1936. L'Art vivant des noirs du Congo belge. Artes Africanae, 3/4: 3-13.

Pirotte, Jean, 1973. Périodiques missionnaires belges d'expression française: reflets de cinquante années d'évolution d'une mentalité, 1889-1940. Louvain: Bibliothèque de l'Université.

Quaghebeur, Marc. 1992. Des textes sous le boisseau. In Quaghebeur, Marc \& Émile Van Balberghe et al. (eds.). Papier blanc, encre noire. Cent ans de culture francophone en Afrique centrale (Zaïre, Rwanda et Burundi), 2 vols. Brussels: Éditions Labor, vii-xciv.

Ricci, Elena. 1998/9. Quelques remarques sur la première Exposition d'art colonial de Rome en 1931: le pavillon belge. Congo-Meuse. L'CEil de l'autre. Colloques de Kinshasa et de Bruxelles, 2/3: 185-201.

Rouch, Jean. 1971. Petit à petit. Paris: Les Films de la Pléiade.

Roy, Chantal. 1943. Thubi, fille noire. Brussels: Buelens.

Said, Edward. 1994 [1993]. Culture and Imperialism. London: Vintage.

Segalen, Victor. 1907. Les Immémoriaux. Paris: Mercure de France. 1978. Essai sur l'exotisme, une esthétique du divers. Paris: Fata Morgana.

2002. Essay on Exoticism: An Aesthetics of Diversity. Trans. and ed. Yaël Rachel Schlick, with a foreword by Harry Harootunian. Durham \& London: Duke University Press.

Antoine Tshitungu Kongolo (ed). 2000. Aux pays du fleuve et des grands lacs. Chocs et rencontres des cultures (de 1885 à nos jours). Brussels: AML Editions.

Van Den Audenaerde, Dirk Thys \& Sony Van Hoecke (eds). 1998. Africa Museum Tervuren 1898-1998. Brussels: Musée Royal de l'Afrique centrale.

Van Overbergh, Cyrille. 1907. Les Mayombe (État Ind. du Congo). Collection de Monographies ethnographiques II. Brussels: Albert Dewit Éditeur \& Institut International de Bibliographie.

Vellut, Jean-Luc. 1994. Ressources scientifiques, culturelles et humaines de l'africanisme en Belgique. Perspectives sur un patrimoine d'outre-mer et sa mise en valeur. Cahiers africains, 9/10/11 (Belgique/ Zaïre. Une histoire en quête d'avenir, Gauthier de Villers [ed.]): 115-44. 